\title{
Mid-Atlantic Ridge: zero-age geochemical variations between Azores and $22{ }^{\circ} \mathrm{N}$
}

\author{
H. Bougault*

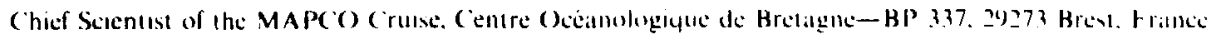

\section{Treuil}

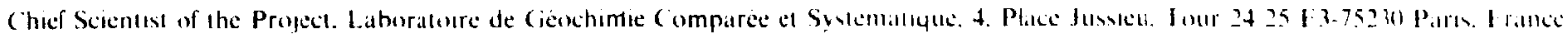

The MAPCO cruise of the RV J. Charcon sampled zero-age hasalts along the Mid-Allamic Ridge lrom the Azores

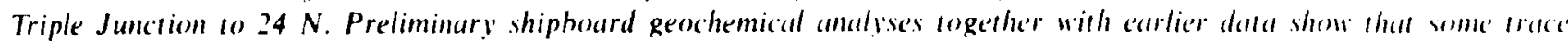
elements are not randomly distributed along the ridge. The latitude of the Hares tramsform delimethe lito regions all

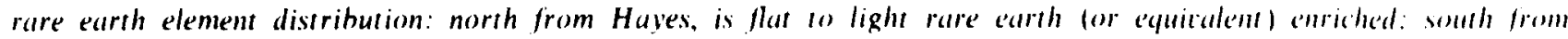
Hayes, is light rare earth for equicalent) depleted. These findings indicate large scale hetcrogencity of the upper mathle'...

THE IPOD program (International Phase for Ocean Driling) has obtained many samples of igneous rocks from the ocean foor during the past five years. The studies related to this sampling and to samples collected by the more classical dredging method have provided many data which have been interpreted and discussed in terms of the fundamental processes of basalt genesis and the composition of the upper mantle. Some of these compositions are impossible to relate (1) one another by conventional magmalic processes of fractional crystallization, accumulation of crystalline phases and partial melting. In addition to these conventional processes, two main hypotheses have been proposed to account for the chemical heterogeneities in oceanic basalts that are observed at different scales. One of these hypotheses invokes magma mixing in one form or another; the second hypothesis assumes primitive heterogeneity of different source regions in the upper mantle. One interpretation does not preclude the other. Mixing. either of more or less fractionated liquids derived from the same source 3 or of liquids derived from different sourcests. is necessarily restricted to local areas. The mande heterogeneity concept can also be considered as a large-scale (regional) property" ${ }^{4}$. The research reported here is an attempl to examine regional heterogeneities along a portion of the MidAllantic Ridge.

\section{Area and techniques of analysis}

The RV J. Charcot is equipped with a multi narrow-heam echo-sounding system (SEABEAM)" which produces a realtime bathymetric map of the sea floor. The system scans an area whose width. normal to the ship's track. is two-thirds of the depth. Because it allows the immediate observation of large scale structures and of fine scale features $(21)-\mathrm{m}$ contour

-The members of the MAPCO (part 1 and 2) scientific team were: J. Y. Bervas, P. Beuzart, P. Cambon. M. El Arrouzi, G. Floch: J. Guichardot-Wirrmann. S. Monti. J. L. Olivet (Centre Oceanolinglyue de Bretagne). J. Durand. S. Savary IIP(j Si-Mauri C:

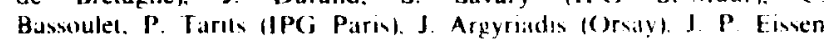

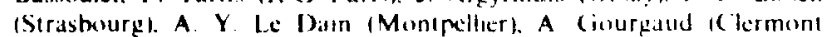
ferrand). P. Feller ITunist. J I Joron. (; Meyer Ilath P Suc, (NRS). J. Siroup (Alhany. IISI A Graham IBriluh Museum INatlural Hislory) London. l|K|\& I) Wind (Birmengham. I KI intervall, the SEABEAM system permils relaltively eilsy recognition of the rift valley and fracture /ones darge-xcillo structures) and choice of a dredge site bassed on observaltion of fine scale features fiuch as, central high, volcallo, steep slope) The objective of our analysis was to lociate the inner floor of the central valley to dredge '/ero atge' bitsilts. The rift valley area chosen for dredging was first surveyed by al track. approximately perpendicular to the ridge axis, roughly 30 miles long 115 miles to either side of the axis). This tralck was enhanced by a return profile locited -1.53 miles 10 the north or south of the initial crossing. In addition to providing information for dredging. each of these trichs constilutes dilti for structural interpretattion. Dredge surveys and intermediate transits allowed us to obtain 54 transects of the ridec between $35 \mathrm{~N}$ and $24 \mathrm{~N}$. Five profiles were made over each of three major transforms, Oceanographer. Hayes and Atlantis.

During this cruise. a new deredging system. atclive weight". was tried and used successfully. It is a percussion sysicm: when the tension of the eathle at the level of aclave weight. which is situated in front of the dredge. I approximattely ? tons, an impulse of 25 tons is communicalled to the dredege. The system can act repeatedly all the bottom 21 is in rencl by a return spring when no lension exists between the active weight and the dredye. Ten dredges along the ridge axis. with tracks of 0.51 .5 miles. were allempled with this sylem and each dredge wast hall full to full of rocks. With this dredging method and with simulaneous Use of SFABFAM. Well positioned dredges can apparently be atchieved with a minimum length of the dredge trick. probahly less thitl 0.5 miles.

Table I Different characteristics between the FAMOUS arcal (36 N and sites 395, $396122 \mathrm{~N}$ ). (Ch for Tat Lat and HIf Lat means normalleded rallow*

\begin{tabular}{|c|c|c|c|c|c|c|}
\hline & $\frac{T_{a_{1}} L_{\text {La }}}{\mathrm{ch}}$ & $\frac{H \mathrm{H}}{\mathrm{L}}$ & $\frac{\text { L.il }}{h}$ & 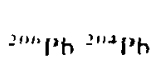 & ${ }^{*} \mathrm{Sr}{ }^{k n} \mathrm{Sr}$ & ANd \\
\hline \multicolumn{7}{|l|}{$22 \mathrm{~N}$} \\
\hline |leg 45, 46) & 0.56 & 2. & -2.6 & $1 \times 0$ & 0.7025 & +13 \\
\hline FAMOUS & $1 .(k)$ & 0.77 & 14 & 18.8 & $0.7012 x$ & +10 \\
\hline
\end{tabular}

* Refor 20,21 


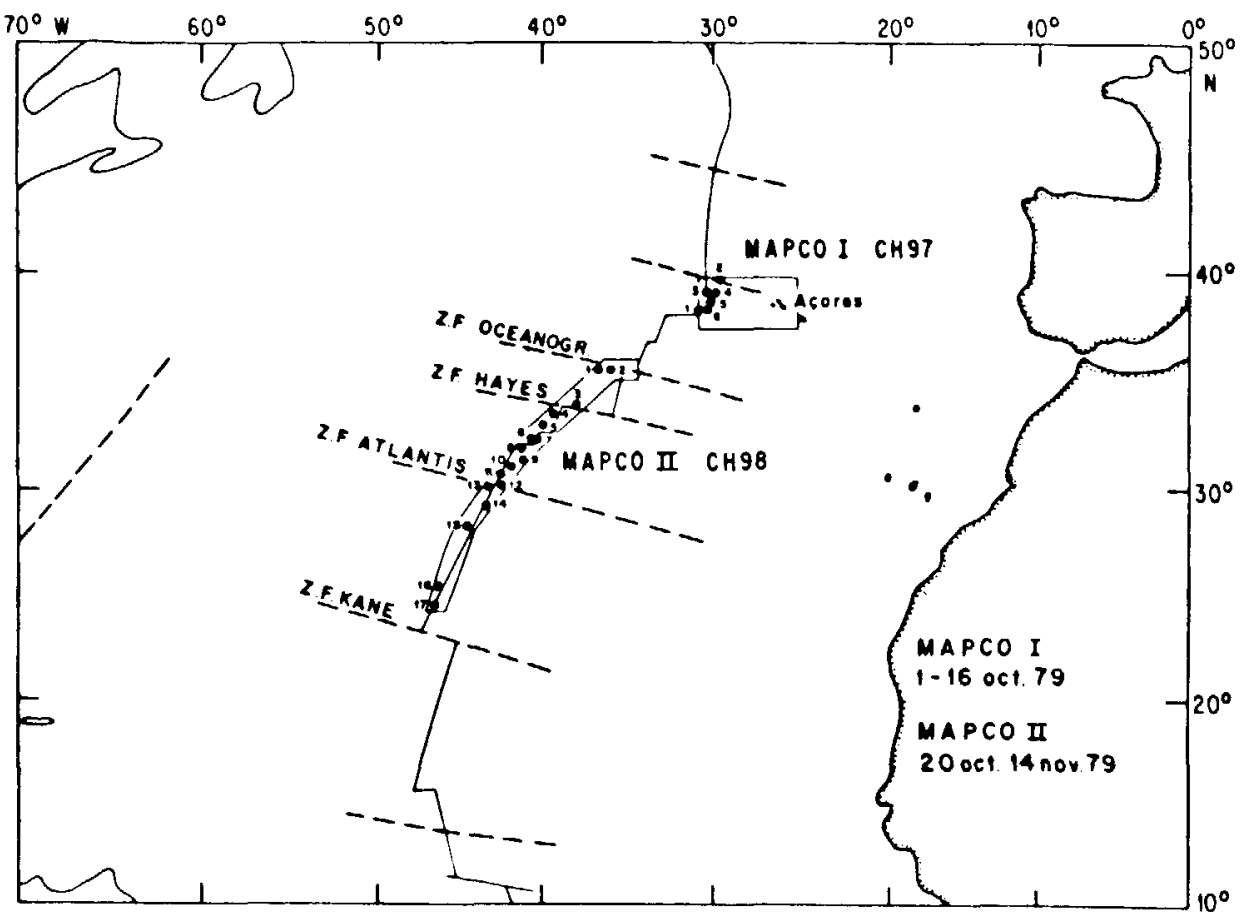

Fig. 1 Map of the studied area. Iots represcent dredge sites.

Thin sections were made on board and an X-ray fluorescence unit, similar to the unit used on board the Glomar Challenger 11.12 , allowed us to obtain selected trace clement and major element data. The precision of the data is comparable to that of an onland laboratory: \pm 1 " (relative) for major elements and \pm 2 p.p.m. (absolute) for trace elements.

The primary objective of the first part of $\mathrm{MAPCO}(\mathrm{CH} \mathrm{97)}$ wats the structural analysis of the Arores Triple Junction between 34) $\mathrm{N}$ and $37 \mathrm{~N}$ (reported elsewhere): the primary objective of the second part of MAPCO $(\mathrm{CH} 98)$ and the secondary objective of MAPCO (CH 97) was to sample zero age basalls from the axis of the Mid-Atlantic Ridge. The secondary objective of $\mathrm{MAPCO}(\mathrm{CH} 98)$ was to collect bottom lopographic profiles, with emphasis on examining the progressive increase in average depth of the rift valley floor from North to South along the ridge.

\section{Results and discussion}

Six dredges were attempled proximal to the Azores Triple Junction during MAPCO $(\mathrm{CH}$ 97) and four of these were successful: 17 dredges were conducted as close as possible to ero age during MAPCO $(\mathrm{CH} 98)$ and 16 were successful (Fig. 1). The morphologic nature of basalt samples recovered during both parts of the cruise is varied. Two-thirds of the total recovered material is comprised of pillow basalt; one-quarter is comprised of segments of glassy crust varying from 1 to $10 \mathrm{~cm}$ in thickness and up to $40 \mathrm{~cm}$ in length. The remainder of the material is comprised of small broken fragments. Most of the samples are remarkably fresh and have clean vitreous surfaces. The pillow basalts exhibit characteristic radial fratcturing, glassy margins. and have very well preserved extrusive forms of lava fingers or tubes up to $15 \mathrm{~cm}$ long. The basalt crusts or sleets are glassy on both sides: the presumed upper portion of hese crusts hats a ropy appearance and the glalss is occilsionally oxidized and veneered by sediment, while the lower surface contains portions of thin vertical walls of large calvities (up $1020 \mathrm{~cm}$ diameter) and or frozen droplets of basalt. In dredges ('H 9811 and 12 we recovered massive glass blocks up to $15 \mathrm{~cm}$ diameter, glass shards, and thin flat sheets $(1 \mathrm{~cm}$ thick $)$ of glatss. The erusts or sheets are interpreted to be either fragments of large pillows or tubes that were rapidly emptied. or fragments of surfaces of lavil lakes ${ }^{13}$. In addition to these bimat samples, scoriaceous basalts of probable subatrial origin were dredged at $900 \mathrm{~m}$ depth in the Azores Triple Junction areal $(\mathrm{CH} 97 \mathrm{DR} 05)$. One fragment of granitic metamorphic rock (garnet, cordierite) and a large number of blocks of sediment were recovered in dredge ( 1198 DR 06 situated roughly 10 miles west of the rift valley axis.

Most of the basalt samples (two-thirds) are aphyric (1) subaphyric (phenocrysts $<5^{\prime \prime}$ ). Nearly all of these hasalt fragments contain a few rounded plagioclase phenocrysts, possibly better referred to as xenocrysts, and one or 1 wo samples also conaain rounded olivine phenocrysts. Microphenocrysts of euhedral olivine, quench olivine and plagioclase are all common. The remainder of the samples are porphyritic basalts $1530^{\circ}$ ". megacrysts, phenocrysts and or microphenocrysts). Plagioclase is by far the dominant phenocryst phase; crystals are as large as $1 \mathrm{~cm}$ in length and are often rounded and partially reversely zoned. Some are belter characterized as glomerocrysts. Most contain inclusions. of glass or microcrystalline material. Olivine is a common, though usually minor, phenocryst phase. It is occasionally seen as rounded crystals up to $0.5 \mathrm{~mm}$ across but is generally subhedral to anhedral and fresh. Olivine contains rare small red-brown spinel. Clinopyroxenc is observed infrequently als a phenocryst phase in these basalts, but is spectacularly present in dredge $\mathrm{CH} 97 \mathrm{DR} 05$ (in the Azores Triple Junction areal) where it forms $15^{\circ}$ "of the rock.

Extensive geochemical data from the northern region (Azores Triple Junction and FAMOUS area) and the southern

Table 2 Duplicate analyses of three samples of $\mathrm{CH} 97 \mathrm{DR} 02 \mathrm{Sr}$, measured from the same pellet preparations as for $\mathrm{Nb}, \mathrm{Zr}$ and $\mathrm{Y}$ determinations. has been used 10 improve the classification of rock types within one dredge. because of its relative higher precision. Ti was moatsured from a glasis disk preparation

\begin{tabular}{|c|c|c|c|c|c|}
\hline & $\mathrm{Sr}$ & $\mathrm{Nb}$ & 7.r & $\mathrm{Ti}$ & $Y$ \\
\hline 101 il & 1380 & 14.1 & 75 & 7.020 & 26 \\
\hline 10$] \mathrm{b}$ & 136.4 & 13.6 & 78 & & \\
\hline $202 \mathrm{~B} \mathrm{a}$ & 141.6 & 13.1 & 76 & 6.900 & 26 \\
\hline $2012 \mathrm{~B} \mathrm{~b}$ & 141.1 & 13.7 & 74 & & 26 \\
\hline 304 it & 150.0 & 15.1 & 71 & 6.720 & 24 \\
\hline 3() $4 \mathrm{~b}$ & 149.3 & 13.1 & 74 & & 24 \\
\hline
\end{tabular}



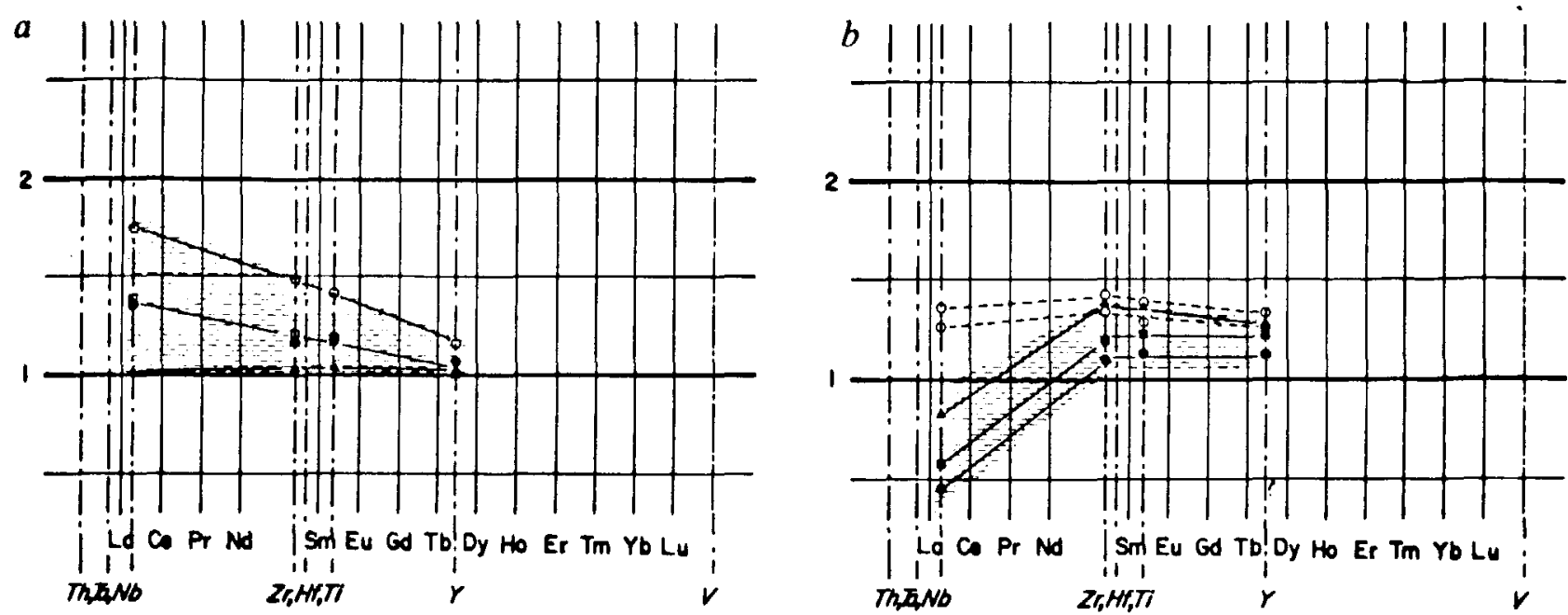

Fig. 2 Examples of extended rare earth diagrams including non rare earth hygromagmaphile efements. a. The spectrum observed it tho Azores Triple Junction FAMOUS area (data from refs 14, 16, 17, 23, 25); $b, 22 \mathrm{~N}$ (data from refs 18, 19. 23). The preferred normalizing abundances corresponding to non rarc carth clements are, in p.p.m.; Th, 0.028: Nb, 0.53: Ta, 0.031: Zr. 5.13: Hf, 0.128: Ti, 460: Y, 2.16: V. 22. In $a$, flat to light rare carth patterns, Nb. Ta and La plot at the same ordinate position (normalized Ta La or Nb/La ratios are $=1 .(09)$ : $h$. light rare earth depleted patterns, $\mathrm{Nb}$ and Ta plot at a lower ordinate position than La (normalized Ta/La ratio is $=0.5$ ) see text.

region ( $22 \mathrm{~N})$ have been interpreted as suggesting that there are significant differences in the isotopic compositions and trace element chemistry of the upper mantle sources between these two areas ${ }^{14} 20$. Table 1 summarizes these data for the FAMOUS area and $22 \mathrm{~N}$ (ref. 21). Clearly from our present knowledge only isotopic data obtained from basalts can be interpreted unambiguously in terms of mantle sources. Hygromagmaphile element ratios such as $\mathrm{Hf} / \mathrm{La}$ (similar to $\mathrm{Zr} / \mathrm{La}$ or $\mathrm{Sm} / \mathrm{La}$ ) in basalts depend on both mantle source and partial melting. The two different ranges of $\mathrm{Hr} / \mathrm{La}$ in the FAMOUS area and at $22 \mathrm{~N}$ are interpretable in terms of different mantle sources (one for each region) in agreement with the isotopic data. The range of this ratio in each area is probably due to different extents or ways of melting ${ }^{22.23}$. As the main target of the MAPCO cruise is the examination of regional heterogeneities along a portion of the Mid-Atlantic
Ridge, namely the transition between the Azores Triple Junction FAMOUS area and $22 \mathrm{~N}$, selected hygromagmaphile elements or their ratios can help, at least in part, to describe these heterogeneities or this transition.

It has been shown for some samples that elements whose ions present a rare gas electronic structure can be included in the rare earth Coryell Masuda plot ${ }^{24.25}$; a comparative geochemical study of more than 300 oceanic basalts showing different rare earth patterns gave precise normalization values and relative behaviour of non rare earth hygromagmaphilc elements compared with rare earth elements ${ }^{26}$. Figure 2 presents such a diagram for samples from the Azores Triple Junction FAMOUS region and from $22 \mathrm{~N}$ (refs $1419,23,25$ ).

In the northern region the extended rare earth patterns are from flat to light rare carth enriched (Azores Triple Junction, FAMOUS, Sites $411,412,413$ and $332,334,335$ of DSDPl:
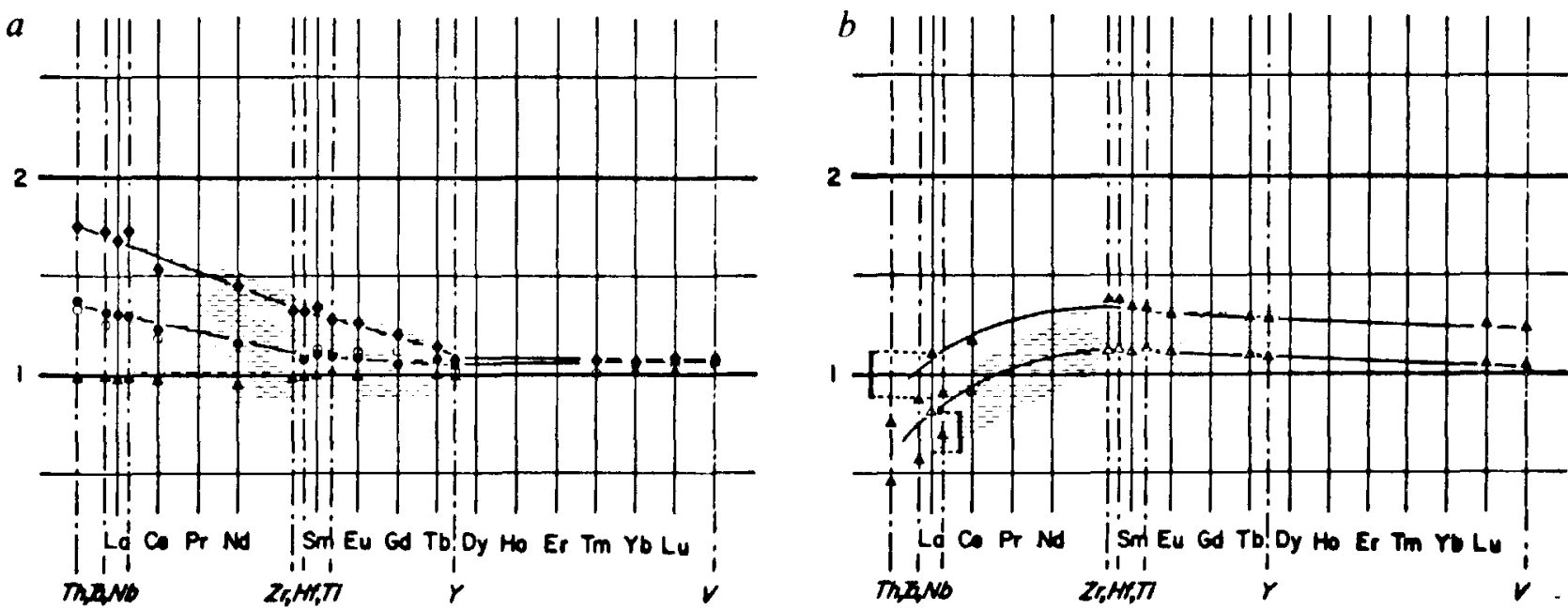

Fig. 3 a, Spectrum of non rare earth normalized patterns observed north from the Hayes transform. The end members of this spectrum are

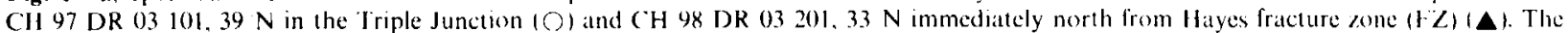
$\square, \mathrm{CH} 97 \mathrm{DR}$ 05 $3 \ldots$ at $38 \mathrm{~N}$. ('H $98 \mathrm{DR} 021 \ldots$ at $35 \mathrm{~N}$ (immediatcly south from Oceanographer FZ) have been chosen as examples showing similar distributions at different latiludes in this areat. $h$. Spectrum of non rare earth normalized patterns observed south from Hayes

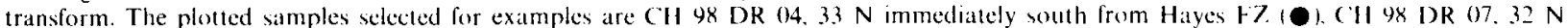

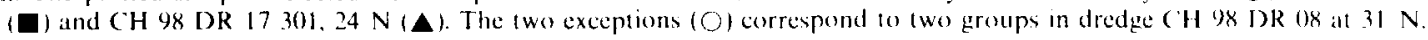


Iable 3 Sr. Nh. Zl. Fi and Y dalla oblatined on boitrd: the figure in parenthene corresponds to the number of analysed salmples

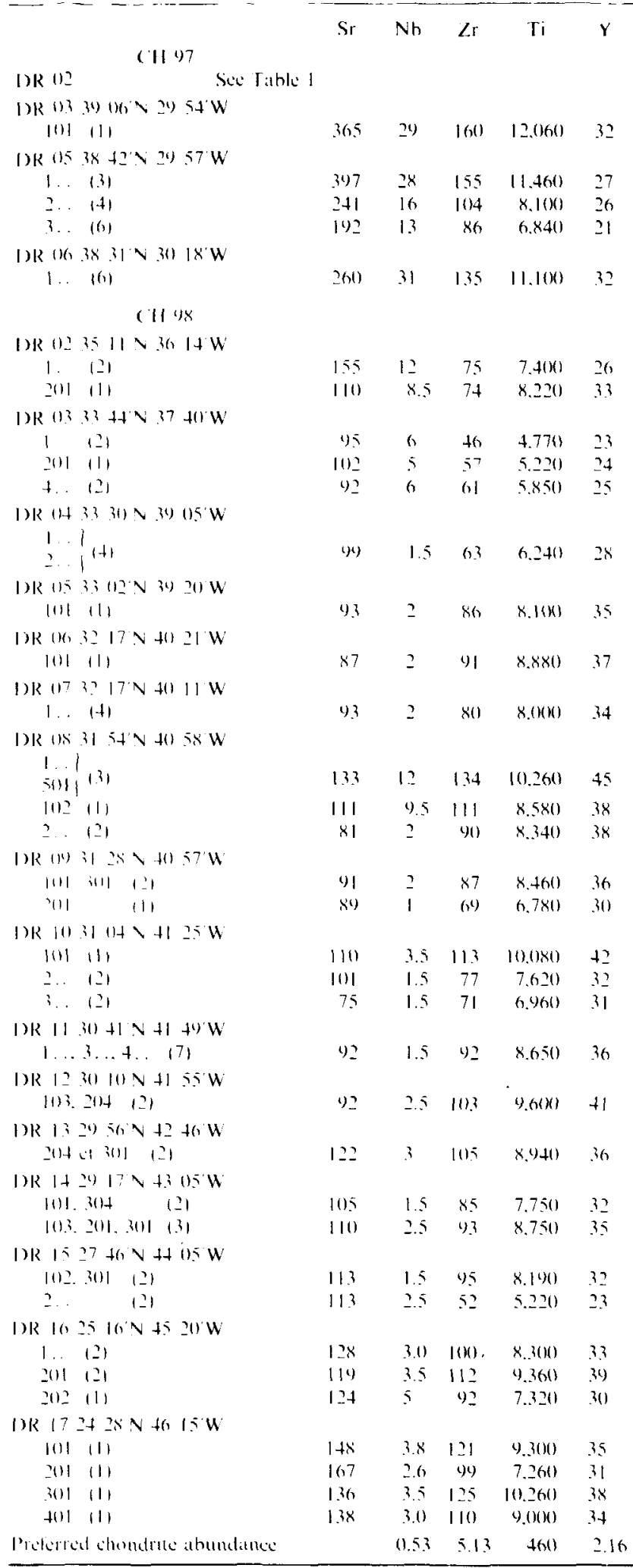

the normalised Tat Lat or Nh Lat ratio $1=11$ is independant of lhe lighlo rate earth enrichment las well als for $45 \mathrm{~N}$. site 40 . and Reghanes stes 407. $4(0 x$ and $4(09)$. In the southern region

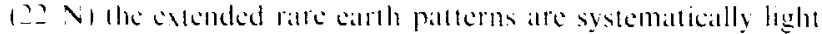
rare carth depleted: the normalized Ta La or $N$ b La ratio is 10.5. Kunwing thes belotviour of hygromagmaphile elements

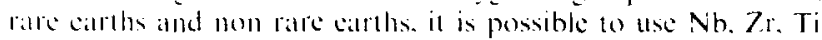

and $Y$ concentrations measured through $X$-ray fluorescence on board to obtain chondrite normalized diagrams equivalent to a rare earth diagram. The data may be interpreted in terms of mantle heterogeneity if these diagrams show sufficienlly large differences as we know that a range of $\mathrm{Sm} / \mathrm{La}$ or $\mathrm{Zr} \mathrm{Nb}$ ratios can be observed within a restricted area (FAMOUS and site 411.412 .413 of DSDP).

Table 2 shows duplicate analyses of samples $(\mathrm{H} 97$ DR 02 used to test the accuracy of measurements on board. Table 3 shows from north to south the results obtained during the cruise. Examination of these data indicates that the distribution of these elements is not random along the axis of the Mid-Allantic Ridge as mentioned for rare earths by White and Schilling ${ }^{2-} \mathrm{Nb}$ concentrations, the most hygromagmaphile element investigated, clearly show lower values in the southern region than in the northern region. The range of variation of $(\mathrm{Nh}, \mathrm{Zr}, \mathrm{Ti}, \mathrm{Y})$ chondrite normalized pitterns are shown in Fig. 3. North from the Hayes transform these patterns are flat to $\mathrm{Nb}$ enriched lequivalent to light rate earth enriched): south from the Halyes transform they are $\mathrm{Nb}$ depleted requivalent to light rare carth depleted: one exception in the soutlern region is observed in CH 98 DR OS where two groups of samples show flat or only slightly $\mathrm{Nb}$ depleted patlerns.

The large difference of the chondrite normalized plots of $\mathrm{Nh}$. Zr. Ti and $Y$ lequivalent to rare earth plots) hetween north and south from Hayes tralnsform allow us 6 interpret these preliminalry results in terms of regional mantle heterogeneity. The suggesled limit datitude of the Hayes transform) will hate to be confirmed by isolopic dalta. It will be also interesting (o) study the Ta La rattio between the Hayes transform and $22 \mathrm{~N}$ to confirm whether or not the single normalized $T_{\text {a }} L a t$ ratio found so far $(=0.5)$ for light rare carth depleted material comparatively to the single value $(=1)$ observed for flat to light rare earth enriched materials

The MAPCO cruise was supported by the Groupe (r. ule Océanique du Comite IPOD France. the (NRs and CNEXO. We thank J. Bonnin for help in formulating thes program and D. Needham for assistance with the cruse plan. The active weight system ased during the crube was developed by J. P. Allenou with the support of J. Y. Bervits. We also thank the Captain. the officers and the crew of the RV J. Charcot. Contribution no. 685 from the Depatrtement de Geophysique. Géologie el Géochimie marines du C.O.B.

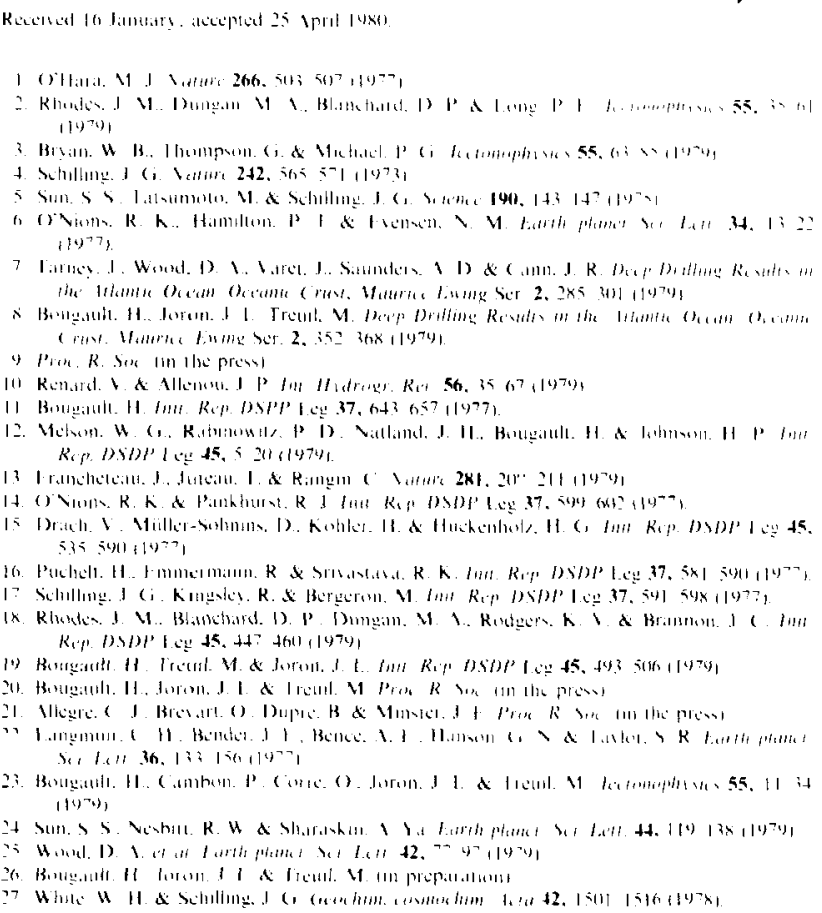

